DEPARTMENT OF THE INTERIOR UNITED STATES GEOLOGICAL SURVEY

PREPARED IN COOPERATION WITH THE COMMONWEALTH OF MASSACHUSETTS

DEPARTMENT OF PUBLIC WORKS

\title{
AEROMAGNETIC MAP OF THE NORWOOD QUADRANGLE, NORFOLK AND SUFFOLK COUNTIES, MASSACHUSETTS
}

\author{
GEOPHYSICAL INVESTIGATIONS \\ MAP GP-763
}

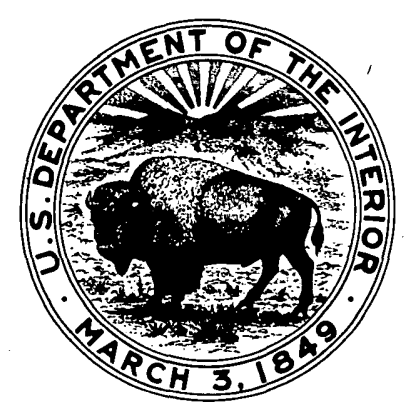

